\title{
Governance in the Family Businesses
}

\section{Learning Objectives}

After reading this chapter, you should be able to:

- Identify unique family business governance characteristics

- Understand the importance of governance in the family business

- Explain the types of family involvement

- Know the differences between private and publicly traded family firms

- Understand the family governance mechanisms and tools

\section{Profile: Firma Roleski}

Marek Roleski founded the company named Firma Roleski as a family business in 1972 in Poland. The bold start-up initiative in agriculture and food industry by Mr. Roleski and his family endured through challenging times due to the communist rule since the 1940s when the national economy was mainly state controlled based on the Soviet model and characterized by the strict rules and regulations of Comecon (Council for Mutual Economic Assistance), an organization of former Eastern-Bloc countries dominated by the Soviet Union. In 1970s, the era in which Firma Roleski started, the Polish economy, was facing limited growth, largely because of government control and subsidies with low productivity.

Despite the drawbacks associated with the struggling economy and ineffective regulatory framework limiting entrepreneurial spirit and effort, Firma Roleski became the first Polish enterprise to transform the state monopoly and obtain license required for mayonnaise production, although the production of mayonnaise was mainly controlled by the government.

However, the country level economic challenges were not over yet. In the late 1980s, an increasing government deficit and hyperinflation resulted in

(continued) 
economic crisis, and then 1989 marked the end of communism and the collapse of Comecon.

In the 1990s, the Polish economy became increasingly involved in the market-oriented global economy. This had a substantial positive impact on Firma Roleski, and the years of resilience and persistence started to pay off. When particularly international retailers and their chains began entering the Polish market, Firma Roleski started growing and expanding with increased demand for Roleski products. This was followed by cooperation with other retail chains.

The developments led to the extension of the product line to include products such as mayonnaise sauces, ketchup, and tomato puree. Then, mustard was introduced to the market, and it quickly became the most popular product category. Roleski mustards (sarepska, horseradish, or table mustard) are still one of the favorites of the Polish consumers to this date. Currently, other Roleski products are sauces and dressings. The company pays close attention to the consumers' preferences and responds to them by delivering expected products and even creating new product categories. By following the healthy food trends, Firma Roleski also innovatively created a line of organic products.

Today, Firma Roleski is proudly promoting itself as a family owned and Polish company with more than 40 years of experience in the food industry by stating that "We put great emphasis on the fact that we are a Polish family business, as we believe this is where the highest quality of our products and our customer-oriented approach stem from." According to Dr. Jacek Lipiec from Warsaw School of Economics in Poland, a family business scholar who takes a closer look at this firm, Firma Roleski is innovative in terms of not only extending the product line but also implementing governance mechanisms and tools by developing a family business constitution in 2010 .

A family business constitution is a formal written agreement including rules and procedures for governing family business relationships, and it is signed by the family business owners. Some may question the rationale for the use of a family business constitution despite the proven success and harmony within the family and the firm. According to Dr. Lipiec, a plane crash the founder Mr. Roleski survived prompted him to have such governance tool to inform and guide the family business members throughout generations.

Eventually, having a family business constitution also helped Firma Roleski maintain and further expand business partnerships as a documented proof of long-term standing. Today, Firma Roleski is still $100 \%$ family owned with a legacy of success along with long-lasting international partners.

\section{Sources}

https://republikaroleski.pl/en/about-us/history/

https://republikaroleski.pl/en/about-us/about-us/ 
https://ffipractitioner.org/the-roleski-constitution/

http://webapps.1sa.umich.edu/ii/PolishRoundTable/pdf/chronology.pdf

https://www.routledge.com/Global-Entrepreneurship-Environment-and-Strat

egy-2nd-Edition/Kshetri/p/book/9781138311213

https://www.britannica.com/place/Poland/Economy

Based on Arteaga and Menéndez-Requejo (2017)

\section{$2.1 \quad$ Introduction}

The key factor distinguishing family firms from others is the family's involvement in the governance of their firm through participation in ownership, management, and board (if any) along with their intentions for maintaining family control over the firm across generations (Chua et al. 1999). Firma Roleski in the profile of this chapter is an example.

The level of family involvement in governance depends on a firm's being private or publicly traded, firm age, firm size, industry in which it operates, and family size as well as other family dynamics (Chrisman et al. 2014; Memili 2011). In the profile firm Firma Roleski, aside from $100 \%$ family ownership and involvement in management, a family constitution is in place not only to ensure the continuity of the family business success but also to facilitate the succession to future generations.

\subsection{Importance of Governance in Family Firms}

Families insert influence on the firm through participation in governance. In turn, this impacts firms' goals, decisions, and performance (Chrisman et al. 2012, 2005a). The unified ownership and control elevate the power and authority of the family (Carney 2005).

Despite the prevalence of family firms across countries, a relatively small percentage of family firms are able to survive throughout generations (Chang et al. 2008; Handler and Kram 1988). For instance, about $30 \%$ of the family firms in the United States pass the business to the second generation, and approximately $10 \%$ transfer the business to the third generation (Beckhard and Dyer 1983a, b). This necessitates effective family governance and support mechanisms and tools. Therefore, in the following sections, types of family involvement, differences in private versus publicly traded family firm governance, and family governance mechanisms and tools are covered at the end of this chapter. 


\subsection{Types of Family Involvement}

\subsubsection{Family Ownership}

When families make equity investment into their ventures, their property rights endow them with legitimacy, authority, and power (Chrisman et al. 2012). When the level of family ownership increases, legitimacy, authority, and power of the family are also elevated. This enables them to be influential on the firm goals, strategies, actions, and performance, if they intend to.

\subsubsection{Family Management and Board Membership}

Aside from family ownership, family's involvement in management and board (if any) facilitates families' exerting influence on the businesses. In fact, management and board memberships represent active family involvement in governance compared to the passive family involvement through ownership only in case when families prefer to play the investor role solely rather than running the company (Andres 2008). Research shows that there is a significant difference between the impact of active (i.e., via management and/or board membership) versus passive family involvement (i.e., via ownership only) on firm performance in particularly larger family firms (Maury 2006; Westhead and Howorth 2006).

\subsubsection{Intra-family Succession Intention}

Intra-family succession intentions, and the increasing number of generations of family members involved in the firm by that, are also a critical component of family governance (Chrisman et al. 2012). Owner management is a characteristic of most small firms. Therefore, ownership and/or management by family members alone may be insufficient to determine if the family will exert its influence to develop goals and strategies that will differ from other owner-managed firms because these components do not indicate if the family has an underlying rationale or willingness to exert its influence (Chua et al. 1999; Dyer 2006; Memili et al. 2011).

In other words, family firms may have the ability to use their discretion to behave differently from non-family firms (Carney 2005), but that does not mean they will do so. Accordingly, family ownership and management that lack the intentions to maintain family control through intra-family succession may not differ significantly in their decision-making processes from those without family involvement because while they have the ability, they lack a critical reason for doing so (Chua et al. 1999). Indeed, the intention for transgenerational control through intra-family succession is an important indication of a family's willingness to use its influence to distinctively affect firm behavior (Memili et al. 2011). Such intentions imply that a firm's strategic behaviors will be oriented toward preserving the economic as well as noneconomic value of the firm for the family in the long run (Gómez-Mejía et al. 2007; Le 


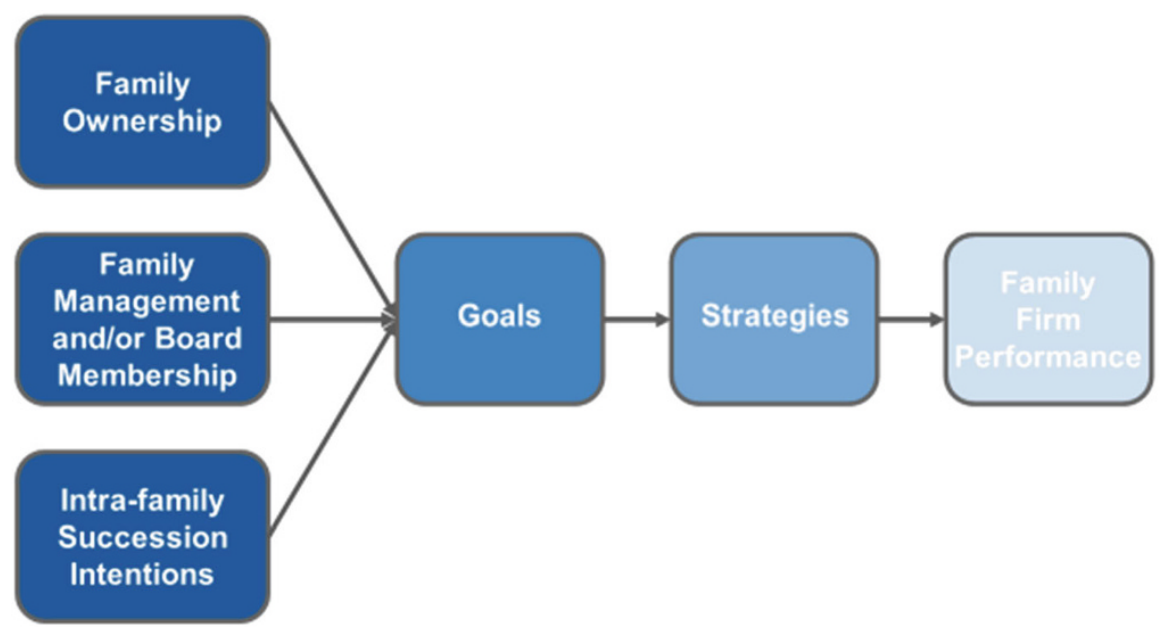

Fig. 2.1 A model for family governance and family firm outcomes. Sources: Adapted from Chrisman et al. (2012); Chua et al. (1999); Memili (2011)

Breton-Miller and Miller 2006). By that, the preference for preserving family involvement makes the family-centered goals such as family harmony, identity, and status even more important (Chrisman et al. 2012).

When a family has distinctive intentions with regard to how the firm should serve the interests of the family, it is likely to develop particularistic strategies that are consistent with those intentions and that differ in meaningful ways from the strategies of non-family firms (Carney 2005). Put differently, when family objectives and business strategies are linked (Aronoff and Ward 1995; Habbershon and Williams 1999), distinctive effects on firm behavior are more likely (Sharma et al. 1997). For example, because intra-family succession requires that the firm survives and prospers as a family institution beyond the life of its founder, the time horizon of its decision makers should be longer than it would otherwise be (Anderson and Reeb 2003; Habbershon and Williams 1999; James 1999; Ward 1997; Zahra et al. 2008). Hence, intra-family succession intentions facilitate a firm-wide long-term orientation.

In sum, family's involvement in governance through ownership, management and/or board membership, and intra-family succession intentions can influence firm goals, strategies, and firm performance (Fig. 2.1). 


\subsection{Private Versus Publicly Traded Family Firms}

\subsubsection{Private Family Firms}

The majority of private businesses across countries are family firms, and they substantially contribute to the economies (Westhead and Howorth 2007). Private family firms initially exhibit unified ownership and management where family members are involved in both (Carney 2005).

As family firms pass the baton from one generation to the next, changes in the level and structure of ownership and management can occur (Westhead and Howorth 2007). For instance, due to increasing family size, more family members may join in ownership. Family firms may also choose to sell ordinary voting shares to other stakeholders such as employees and/or external individuals/parties. Therefore, ownership of the private family firm may be mostly held by a family group or it can be dispersed by including owners outside the family (Westhead and Howorth 2007). For example, the profile firm Firma Roleski at the beginning of this chapter represents a private family firm where $100 \%$ of the ownership is held by the family group. Another private family firm Sheetz, according to the Chair and CEO Joe Sheetz, $90 \%$ is owned by about 85 Sheetz family members, and the rest by 16,000 employees through an employee stock ownership plan. This plan allows any employee at Sheetz with more than a year employment to own stock of the company, as well as hundreds of former employees (Altoona Mirror 2015).

\subsubsection{Publicly Traded Family Firms}

Many publicly traded firms across countries are controlled by the founding families despite the common presumption that family firms tend to be small and medium sized (Villalonga and Amit 2006a, b, 2009; Memili 2011). In corporations, family involvement occurs when a family participates in corporate governance through ownership and management and/or board (Chrisman et al. 2004, 2005b; Memili 2011). Hence, family controlled publicly traded firms are those in which the founders or the family group take the officer, director, or large shareholder role (s) (Villalonga and Amit 2009; Memili 2011). This type of family involvement can affect corporate goals and strategies (Carney 2005), in turn impacting family firm behavior and performance which are expected to be distinct from those in non-family firms within the corporate context (Memili 2011).

There is variation in the level of family involvement in corporate governance across countries. For example, in the United States, ownership in corporations is relatively more dispersed in order to minimize blockholdership of one individual, group, or entity (Gedajlovic and Shapiro 1998; Memili 2011). The US legal system also enforces that shareholdings are diffused (Morck and Steier 2005; Memili 2011). Additionally, litigious shareholders and the corporate takeover mechanism legally available can discipline or eliminate ineffective corporate members, including large shareholders (Memili 2011; Morck et al. 2005). However, families can maintain or 
elevate their control by using control- enhancing mechanisms which can elevate voting rights over their cash flow rights (Memili 2011; Villalonga and Amit 2006a, b). For example, the controlling family's voting rights largely exceeded its cash flow rights at the Ford Motor Co., whereas in 1998, the Ford family owned only $6 \%$ of the shares while holding $40 \%$ of the votes via dual-class shares (Memili 2011; Villalonga and Amit 2006b). In Europe and Asia, families' ownership and involvement in management and/or board in publicly traded family firms appear to be at higher levels (Jiang and Peng 2011; Maury 2006).

\subsection{Family Governance Mechanisms and Tools}

\subsubsection{Family Council and Assembly}

Aside from the main components of family involvement in governance through ownership, management and/or board membership, and succession intentions, there are also mechanisms and tools legally available to families in how they manage their firms as well as family relations.

Family assembly is a periodic, generally annual gathering of the extended family (Gersick and Feliu 2014), whereas the family council is a group of family members who meet regularly to discuss and make decisions on the issues related to the family's involvement in the firm (Gersick et al. 1997; Melin and Nordqvist 2007). The family council is often above the board of directors with decisions parallel to the owners' annual meeting (Melin and Nordqvist 2007).

In relatively larger families, these family governance mechanisms also help manage inter-family conflicts by balancing the interests of the different subgroups of the family that are involved in the firm (Van Aaken et al. 2017). Moreover, family assemblies and councils provide a forum in which different values, opinions, and attitudes about the firm are provided and presented to the firm management. Effective communication can help family members with variant interests reach agreement on various issues, stay in line with management, and strengthen the emotional bonds within the family (Van Aaken et al. 2017).

Family assemblies and councils can also advise, monitor, and support management (Van Aaken et al. 2017). For example, when management needs to make difficult decisions such as implementation of change or the dismissal of family members, family councils can facilitate the decision-making process. Family assemblies and councils can also assist in resolving policy issues such as the rights and responsibilities of family business owners and managing relations between family managers and non-family managers (Gersick et al. 1997).

\subsubsection{Family Constitution}

A family constitution, often referred to as a family protocol, or family creed, or family agreement, is a legal written agreement signed by family business owners 
including a set of rules and procedures for governing the members' relationships (Arteaga and Menéndez-Requejo 2017). Family constitutions may involve the firm history and the future vision and mission of the family firm by also providing norms and rules for family members regarding their roles in the business. Other topics of interest are succession planning and shareholder agreements such as the transfer of shares, dividends, firm valuation, and power structure. This helps continuity of the family firm throughout generations by providing a road map.

In the profile firm Firma Roleski, we have covered that transgenerational intrafamily succession intentions led to the necessity for the founding family to develop and implement a family constitution. This has been helping the family firm not only guide current and future generations but also signal the long-term orientation of the business to other stakeholders such as business partners and alliances.

\subsubsection{Family Charter}

A family charter represents the code of conduct to the family business members (Michiels et al. 2015). It can facilitate the development of formal policies by documenting principles and guidelines regarding the relationship of the family to the business (Michiels et al. 2015). Since the development of a family charter is usually through the participation of the entire family, it can help maintain family unity, culture, and transparency (Michiels et al. 2015; Poza 2009).

\subsection{Summary}

This chapter focuses on the unique family business governance characteristics and explains how family governance is different from the governance in non-family firms. Additionally, governance variations among family firms (e.g., private vs. publicly traded) are discussed. After also highlighting the importance of governance in the family business, different types of family involvement in governance (i.e., family ownership, family management and board membership, and intra-family succession intentions) are covered. Other governance mechanisms and tools available to family firms are family council and assembly, family constitution, and family charter.

While the level and type of family involvement vary among family firms depending of the families' preference and internal environment such as firm size, family size, firm age, and generation in charge, they are also affected by the factors in the external environment such as industry and overall entrepreneurial ecosystem encompassing regulatory framework, access to finance, market, technology, research and development (R\&D), culture, values, and skills (Kshetri 2019). 


\section{Case Study: Marriott International Inc.}

The founder J. Willard Marriott and his wife, Alice, started their small family business initially as the first A\&W root beer stand franchise in Washington, D.C., in 1927. Their mission to provide "good food and good service at a fair price" set the foundation for Hot Shoppes restaurants, and then for Marriott International as their family business grew. Soon after the A\&W franchise start-up, the Hot Shoppes restaurants emerged by adding food items to the menu within the same year by the Marriotts. Just a year later, Hot Shoppes started branching out by also creating the first drive-in restaurant in East Coast. In 1953, Hot Shoppes, Inc. stock became public at $\$ 10.25 /$ share and sold out in 2 hours of trading.

After the successes in the restaurant industry, Marriott family started their hotel business in 1957. Under the management of J. Willard Marriott's son, Bill, the world's first motor hotel opened in Arlington, VA. The following 25 years, Marriott became an exemplary global family business which has been substantially influential in the hospitality industry.

When J. Willard Marriot passed away in 1985, the son J. W. (Bill) Marriott, Jr. was elected Chair of the Board. His involvement in the family business early on facilitated a successful transition in governance. Bill Marriott then led the company to become a multinational corporation during his long career. In 2012, at age 80, he transferred the CEO responsibilities over to Arne Sorenson with the title of President and CEO of Marriott International Inc. Arne Sorenson was also well prepared for the leadership role because of his former Chief Operating Officer and other positions at Marriott International Inc. since he joined Marriott in 1996 although he was a non-family executive, and the norm was to pass leadership to a family member until that time at Marriott International Inc.

Through new leadership along with other family members involved in corporate governance, Marriott International Inc. continued to grow successfully with many brands within the company. In 2016, Marriott International Inc. became the world's largest hotel company across 30 brands such as Marriott Hotels \& Resorts, Courtyard by Marriott, Fairfield Inn by Marriott, and many more in over 110 countries.

However, the successful company is not immune from the unexpected threat and damaging effects of COVID-19 outbreak on the hospitality and tourism industry that started in early 2020. In an emotional video message on March 19, 2020, to Marriott International employees, CEO Arne Sorenson considered the coronavirus crisis as more severe for the hotel chain than the Great Depression and World War II. He also informed that the global business performance was about $75 \%$ lower than normal with hundreds of hotels closing, and some may never reopen. According to him, this financial situation 
is the most challenging in the company's history. Arne Sorenson also explained that initial actions such as executive pay suspension and cuts, suspension of marketing and advertising, and hiring freeze with the exception of critical positions have been taken.

\section{Questions}

1. In the short run, aside from the measures taken, what other actions will you recommend to Arne Sorenson in dealing with this crisis associated with COVID-19 outbreak?

2. What issues in terms of corporate governance can Marriott International Inc. face in the long run in this family business? How can they be solved?

3. What could be the advantages and disadvantages of being a family business while dealing with this type of crisis?

\section{Sources}

https://www.marriott.com/about/culture-and-values/history.mi https://news.marriott.com/leadership/arne-m-sorenson https://news.marriott.com/news/2020/03/13/a-message-from-our-ceo https://twitter.com/MarriottIntl?ref_src=twsrc\%5Etfw\%7Ctwcamp\%

5Etweetembed\%7Ctwterm\%5E1240639160148529160\&ref_url=https\% 3A\%2F\%2Ffinance.yahoo.com\%2Fnews\%2Fmarriott-ceo-sorensondetails-crisis-161524903.html

\section{Questions for Discussion}

- What are unique family business governance characteristics?

- Why is governance important in the family business?

- Explain the types of family involvement

- What are the differences between private and publicly traded family firms?

- Explain the family governance mechanisms and tools

\section{Additional Readings}

- Bennedsen, M., Pérez-González, F., \& Wolfenzon, D. (2010). The governance of family firms. Corporate governance: A synthesis of theory, research, and practice, 8, 371-389.

- Carney, M. (2005). Corporate governance and competitive advantage in familycontrolled firms. Entrepreneurship theory and practice, 29(3), 249-265.

- Chrisman, J. J., Chua, J. H., Pearson, A. W., \& Barnett, T. (2012). Family involvement, family influence, and family-centered non-economic goals in small firms. Entrepreneurship theory and practice, 36(2), 267-293.

- Chua, J. H., Chrisman, J. J., \& Sharma, P. (1999). Defining the family business by behavior. Entrepreneurship theory and practice, 23(4), 19-39. 
- Gnan, L., Montemerlo, D., \& Huse, M. (2015). Governance systems in family SMEs: The substitution effects between family councils and corporate governance mechanisms. Journal of Small Business Management, 53(2), 355-381.

- Miller, D., \& Le Breton-Miller, I. (2006). Family governance and firm performance: Agency, stewardship, and capabilities. Family business review, 19(1), 73-87.

- Suess, J. (2014). Family governance-Literature review and the development of a conceptual model. Journal of Family Business Strategy, 5(2), 138-155.

\section{Suggested Activities}

- Select one private family business and one publicly traded family firm. List the similarities and differences between them.

- Find a family business applying a governance mechanism or tool such as family assembly, and/or family council, and/or family constitution. Analyze the effects on the family involved in the business and the family firm.

\section{Keywords}

- Family governance

- Family involvement

- Family ownership

- Family management

- Family board membership

- Intra-family succession

- Private family firm

- Publicly traded family firm

- Family council

- Family assembly

- Family charter

- Family constitution

\section{References}

Altoona Mirror. (2015). Sheetz says Forbes got it wrong. Winsight, LLC. Available at https://www. cspdailynews.com/company-news/sheetz-says-forbes-got-it-wrong . Accessed 23 Mar 2020

Anderson, R. C., \& Reeb, D. M. (2003). Founding-family ownership, corporate diversification, and firm leverage. The Journal of Law and Economics, 46(2), 653-684.

Andres, C. (2008). Large shareholders and firm performance-An empirical examination of founding-family ownership. Journal of Corporate Finance, 14(4), 431-445.

Aronoff, C. E., \& Ward, J. L. (1995). Family-owned businesses: A thing of the past or a model for the future? Family Business Review, 8(2), 121-130.

Arteaga, R., \& Menéndez-Requejo, S. (2017). Family constitution and business performance: Moderating factors. Family Business Review, 30(4), 320-338.

Beckhard, R., \& Dyer Jr, W. G. (1983a). SMR forum: Managing change in the family firm-Issues and strategies. Sloan Management Review (pre-1986), 24(3), 59.

Beckhard, R., \& Dyer Jr, W. G. (1983b). Managing continuity in the family-owned business. Organizational Dynamics, 12(1), 5-12. 
Carney, M. (2005). Corporate governance and competitive advantage in family-controlled firms. Entrepreneurship Theory and Practice, 29(3), 249-265.

Chang, E. P., Chrisman, J. J., Chua, J. H., \& Kellermanns, F. W. (2008). Regional economy as a determinant of the prevalence of family firms in the United States: A preliminary report. Entrepreneurship Theory and Practice, 32(3), 559-573.

Chrisman, J. J., Chua, J. H., \& Litz, R. A. (2004). Comparing the agency costs of family and non-family firms: Conceptual issues and exploratory evidence. Entrepreneurship Theory and practice, 28(4), 335-354.

Chrisman, J. J., Chua, J. H., Pearson, A. W., \& Barnett, T. (2012). Family involvement, family influence, and family-centered non-economic goals in small firms. Entrepreneurship Theory and Practice, 36(2), 267-293.

Chrisman, J. J., Chua, J. H., \& Sharma, P. (2005a). Trends and directions in the development of a strategic management theory of the family firm. Entrepreneurship Theory and Practice, 29(5), $555-575$.

Chrisman, J. J., Chua, J. H., \& Steier, L. (2005b). Sources and consequences of distinctive familiness: An introduction. Entrepreneurship Theory and Practice, 29(3), 237-247.

Chrisman, J. J., Memili, E., \& Misra, K. (2014). Nonfamily managers, family firms, and the winner's curse: The influence of noneconomic goals and bounded rationality. Entrepreneurship Theory and Practice, 38(5), 1-25.

Chua, J. H., Chrisman, J. J., \& Sharma, P. (1999). Defining the family business by behavior. Entrepreneurship Theory and Practice, 23(4), 19-39.

Dyer Jr, W. G. (2006). Examining the "family effect" on firm performance. Family Business Review, 19(4), 253-273.

Gedajlovic, E. R., \& Shapiro, D. M. (1998). Management and ownership effects: Evidence from five countries. Strategic Management Journal, 19(6), 533-553.

Gersick, K. E., \& Feliu, N. (2014). Governing the family enterprise: Practices, performance, and research. In L. Melin, M. Nordqvist, \& P. Sharma (Eds.), The SAGE handbook of family business (pp. 196-225). London: Sage.

Gersick, K., Davis, J., Hampton, M. M., \& Lansberg, I. (1997). Generation to generation: Life cycles of the family business. Boston, MA: Harvard Business School Press.

Gómez-Mejía, L. R., Haynes, K. T., Núñez-Nickel, M., Jacobson, K. J., \& Moyano-Fuentes, J. (2007). Socioemotional wealth and business risks in family-controlled firms: Evidence from Spanish olive oil mills. Administrative Science Quarterly, 52(1), 106-137.

Habbershon, T. G., \& Williams, M. L. (1999). A resource-based framework for assessing the strategic advantages of family firms. Family Business Review, 12(1), 1-25.

Handler, W. C., \& Kram, K. E. (1988). Succession in family firms: The problem of resistance. Family Business Review, 1(4), 361-381.

James, H. S. (1999). Owner as manager, extended horizons and the family firm. International Journal of the Economics of Business, 6(1), 41-55.

Jiang, Y., \& Peng, M. W. (2011). Are family ownership and control in large firms good, bad, or irrelevant? Asia Pacific Journal of Management, 28(1), 15-39.

Kshetri, N. (2019). Global entrepreneurship: Environment and strategy (2nd ed.). New York: Routledge, Taylor \& Francis.

Le Breton-Miller, I., \& Miller, D. (2006). Why do some family businesses out-compete? Governance, long-term orientations, and sustainable capability. Entrepreneurship Theory and Practice, 30(6), 731-746.

Maury, B. (2006). Family ownership and firm performance: Empirical evidence from Western European corporations. Journal of Corporate Finance, 12(2), 321-341.

Melin, L., \& Nordqvist, M. (2007). The reflexive dynamics of institutionalization: The case of the family business. Strategic Organization, 5(3), 321-333. https://doi.org/10.1177/ 1476127007079959.

Memili, E. (2011). Control-enhancing corporate governance mechanisms: Family versus nonfamily publicly traded firms. Mississippi State University. 
Memili, E., Chrisman, J. J., Chang, E. P. C., \& Kellermanns, F. W. (2011). Der Einfluß von Marktorientierung und innerfamiliären Nachfolgeintentionen auf die Wettbewerbsposition von Kleinunternehmen [The influence of market orientation and intra-family succession intentions on the competitive positioning of small firms]. Betriebswirtschaftliche Forschung und Praxis (Family Firm Special Issue), 63(6), 606-627.

Michiels, A., Voordeckers, W., Lybaert, N., \& Steijvers, T. (2015). Dividends and family governance practices in private family firms. Small Business Economics, 44(2), 299-314.

Morck, R., \& Steier, L. (2005). The global history of corporate governance: An introduction. In R. Morck (Ed.), A history of corporate governance around the world: Family business groups to professional managers (pp. 1-64). Chicago: University of Chicago Press.

Morck, R., Wolfenzon, D., \& Yeung, B. (2005). Corporate governance, economic entrenchment, and growth. Journal of Economic Literature, 43(3), 655-720.

Poza, E. (2009). Rediscovering just how much patient family ownership matters. Family Business, 20(4).

Sharma, P., Chrisman, J. J., \& Chua, J. H. (1997). Strategic management of the family business: Past research and future challenges. Family Business Review, 10(1), 1-35.

Ward, J. L. (1997). Growing the family business: Special challenges and best practices. Family Business Review, 10(4), 323-337.

Van Aaken, D., Rost, K., \& Seidl, D. (2017). The substitution of governance mechanisms in the evolution of family firms. Long Range Planning, 50(6), 826-839.

Villalonga, B., \& Amit, R. (2006a). How do family ownership, management, and control affect firm value? Journal of Financial Economics, 80(2), 385-417.

Villalonga, B., \& Amit, R. (2006b). Benefits and costs of control-enhancing mechanisms in U. S. family firms. ECGI WP Series in Finance, 209.173.247.216.

Villalonga, B., \& Amit, R. (2009). How are US family firms controlled? The Review of Financial Studies, 22(8), 3047-3091.

Westhead, P., \& Howorth, C. (2006). Ownership and management issues associated with family firm performance and company objectives. Family Business Review, 19(4), 301-316.

Westhead, P., \& Howorth, C. (2007). 'Types' of private family firms: An exploratory conceptual and empirical analysis. Entrepreneurship and Regional Development, 19(5), 405-431.

Zahra, S. A., Hayton, J. C., Neubaum, D. O., Dibrell, C., \& Craig, J. (2008). Culture of family commitment and strategic flexibility: The moderating effect of stewardship. Entrepreneurship Theory and Practice, 32(6), 1035-1105. 